\title{
Correction to: Choose Your Evidence
}

\section{Scientific Thinking Where It May Most Count}

\section{Deanna Kuhn $^{1}$ (D) Anahid S. Modrek ${ }^{2}$}

Published online: 13 August 2021

(c) The Author(s), under exclusive licence to Springer Nature B.V. 2021

\section{Correction to: Science \& Education}

$$
\text { https://doi.org/10.1007/s11191-021-00209-y }
$$

The original version of this article unfortunately contains incorrect article title due to a typesetting mistake.

The corrected article title is presented above.

The original article has been corrected.

Publisher's Note Springer Nature remains neutral with regard to jurisdictional claims in published maps and institutional affiliations.

The online version of the original article can be found at https://doi.org/10.1007/s11191-021-00209-y

Deanna Kuhn

dk100@tc.columbia.edu

1 Columbia University Teachers College, New York, NY, USA

2 Thomas Jefferson University, Philadelphia, PA, USA 